\title{
CoreValve transcatheter aortic valve implantation complicated by stress cardiomyopathy (tako-tsubo) and septic shock
}

Przezskórna implantacja sztucznej zastawki aortalnej typu CoreValve powikłana kardiomiopatią stresową (tako-tsubo) i wstrząsem septycznym

\author{
Dorota Kustrzycka-Kratochwil', Agata Makowska², Piotr Kübler', Artur Telichowski', Waldemar Banasiak', \\ Ewa Jankowska ${ }^{1,3}$, Piotr Ponikowski, ${ }^{1,3}$ Krzysztof Reczuch ${ }^{1,3}$ \\ 1Department of Cardiology, Military Hospital, Wroclaw, Poland \\ 2Students Scientific Association, Department of Heart Diseases, Wroclaw Medical University, Poland \\ ${ }^{3}$ Department of Heart Diseases, Wroclaw Medical University, Poland
}

Postep Kard Inter 2012; 8, 4 (30): 335-337

DOI: $10.5114 /$ pwki.2012.31915

\begin{abstract}
Transcatheter aortic valve implantation (TAVI) has become a promising alternative for surgical therapy of patients with severe aortic stenosis. Transcatheter aortic valve implantation procedures are currently limited to patients who have been disqualified from surgery because of high operative risk, but they are associated with specific complications. We report a case of an 82 -year-old woman undergoing TAVI. The patient was not considered as a good candidate for surgery due to elevated risk (logistic EuroSCORE 24\%). The procedure alone was uncomplicated, performed through the transfemoral access with a $29 \mathrm{~mm}$ CoreValve bioprosthesis. Unfortunately, 20 days after the procedure the patient's condition suddenly deteriorated, with symptoms of acute heart failure and chest pain, followed by shock and with accompanying sepsis. Based on clinical findings, inverted T waves in ECG precordial leads, elevated levels of troponin, echocardiography with new regional wall motion abnormalities and angiography (normal coronary arteries) the diagnosis of stress cardiomyopathy (tako-tsubo like cardiomyopathy) was made. After intensive pharmacological treatment with haemodynamic monitoring the patient's condition gradually improved. Echocardiography revealed gradual regression of regional wall motion abnormalities and improvement of left ventricular function. The case indicates the possibility of less typical complications of TAVI, like takotsubo syndrome, and should be considered in differential diagnosis of chest pain in patients undergoing this procedure.
\end{abstract}

Key words: transcatheter aortic valve implantation, tako-tsubo

\section{Streszczenie}

Zabieg przezskórnej implantacji zastawki aortalnej (transcatheter aortic valve implantation - TAVI) stanowi obiecującą alternatywę dla leczenia chirurgicznego u pacjentów z ciężką stenozą aortalną. Zaleca się go osobom, które zostały wykluczone z zabiegu chirurgicznego z powodu wysokiego ryzyka. Zabieg ten wiąże się jednak z określonymi powikłaniami. Przedstawiono przypadek 82-letniej pacjentki poddanej zabiegowi TAVI. Ze względu na zwiększone ryzyko (Logistic EuroScore 24\%) pacjentka nie była dobrą kandydatką do leczenia operacyjnego. Zabieg wykonany z dostępu przez tętnicę udową, z implantacją zastawki CoreValve 29 mm, przebiegł bez komplikacji. Niestety 20 dni po procedurze stan pacjentki nagle się pogorszył. Stwierdzono objawy ostrej niewydolności serca i ból w klatce piersiowej z następczym wstrząsem i towarzyszącą sepsą. Na podstawie oceny klinicznej, zapisów elektrokardiograficznych z ujemnymi załamkami T w odprowadzeniach przedsercowych, zwiększonego stężenia troponiny, nowych regionalnych zaburzeń kurczliwości w badaniu echokardiograficznym i wyniku angiografii (z prawidłowymi naczyniami wieńcowymi) rozpoznano kardiomiopatię stresową (zespół tako-tsubo). Stan chorej stopniowo się poprawił po intensyfikacji leczenia farmakologicznego, wraz z monitorowaniem hemodynamicznym. W echokardiografii wykazano stopniowe ustąpienie regionalnych zaburzeń kurczliwości i poprawę funkcji lewej komory. Przedstawiony przypadek wskazuje na możliwość wystąpienia mniej typowego powikłania zabiegu TAVI - zespołu tako-tsubo, który powinien być rozpatrywany w diagnostyce różnicowej bólów w klatce piersiowej u pacjentów poddanych tej procedurze.

Słowa kluczowe: przezskórna implantacja zastawki aortalnej, tako-tsubo

Corresponding author/Adres do korespondencji:

Piotr Kübler MD, PhD, Department of Cardiology, Military Hospital, 5 Weigla St, 50-981 Wroclaw, Poland, tel.: +48 7176604 52, e-mail: pkubler75@qmail.com

Praca wptynęła: 6.09.2012, przyjęta do druku: 13.09.2012. 


\section{Introduction}

Transcatheter aortic valve implantation (TAVI) was started in 2002 by Alain Cribier and currently has become a promising alternative for surgical therapy [1]. The TAVI procedures are currently limited to patients with severe stenosis, who have been disqualified from surgery because of high operative risk, and are associated with specific complications [2].

We report a case of a patient undergoing TAVI complicated by stress cardiomyopathy (tako-tsubo like cardiomyopathy) followed by shock and with accompanying sepsis.

\section{Case report}

An 82-year-old woman with a few years history of severe aortic stenosis, several episodes of syncope and with symptoms of heart failure in NYHA class III was referred to our department for further evaluation. The patient was not considered as a good candidate for surgery due to elevated risk related to her age, chronic renal failure, anaemia, diabetes and with co-existing rheumatic disease potentially complicating post-operative recovery (logistic EuroSCORE 24\%).

Echocardiography revealed normal left ventricular diameter with moderate hypertrophy, with no regional wall motion abnormalities and with left ventricular ejection fraction (LVEF) of $60 \%$. The diagnosis of complex aortic valve dysfunction with predominant severe stenosis was confirmed. The maximal aortic gradient was $81 \mathrm{~mm} \mathrm{Hg}$, mean $51 \mathrm{~mm} \mathrm{Hg}$, aortic valve area was estimated as $0.8 \mathrm{~cm}^{2}$ and mild insufficiency of both atrioventricular valves was found. The parameters of the aorta and aortic valve morphology fulfilled the criteria for TAVI with the aortic annulus diameter estimated as

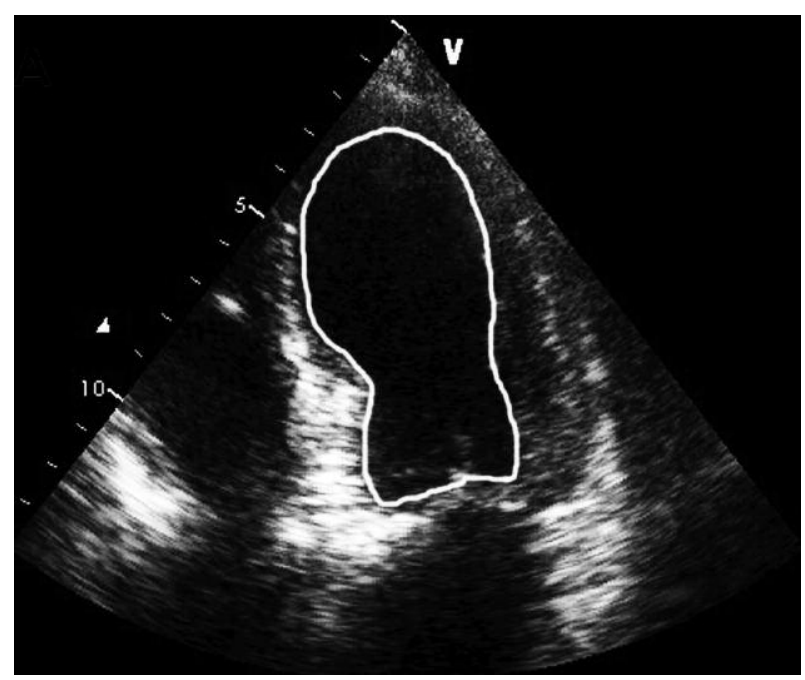

Fig. 1. Echocardiography - white line outlines regional wall motion abnormalities with apical akinesis of left ventricle

Ryc. 1. Echokardiografia - biatą linią obrysowano obszar regionalnych zaburzeń kurczliwości lewej komory z akinezą koniuszka
24-25 mm. Other imaging studies of peripheral arteries and aorta suggested favourable anatomy. Angiogram revealed normal coronary arteries. ECG prior to the procedure showed sinus rhythm with left anterior hemiblock.

The patient underwent TAVI through the transfemoral access with a $29 \mathrm{~mm}$ CoreValve bioprosthesis. The procedure was performed in general anaesthesia with transoesophageal echocardiography monitoring. After the procedure the patient was transferred to the Intensive Cardiac Monitoring Unit in good general condition, haemodynamically stable, and after 2 days transferred to a normal ward. Repeated echocardiography revealed normal diameter of the left ventricle with normal contractility and satisfactory systolic flow through the implanted valve with a maximal gradient of $20 \mathrm{~mm} \mathrm{Hg}$. However, persistent moderate aortic regurgitation with two paravalvular jets and moderate to severe mitral insufficiency were present. After the procedure the patient complained of a persistent cough, inflammation markers were elevated and an intravenous antibiotic was started.

Suddenly 20 days after the procedure the patient's condition deteriorated. She reported weakness, chest discomfort and dyspnoea. ECG showed inverted T waves in precordial leads. Blood pressure dropped to $90 / 60 \mathrm{~mm} \mathrm{Hg}$. Urgently performed echocardiography clearly revealed new regional wall motion abnormalities with akinesis of the apex, apical segments of anterior and antero-septal wall with LVEF of 30-35\% and increased end-diastolic left ventricular diameter up to $60 \mathrm{~mm}$ (Fig. 1). Acute coronary syndrome was suspected, but coronary angiography revealed normal coronary arteries. Cardiac ventriculography confirmed the presence of widespread regional wall motion abnormalities with ballooning of the apex (Fig. 2). Elevat-

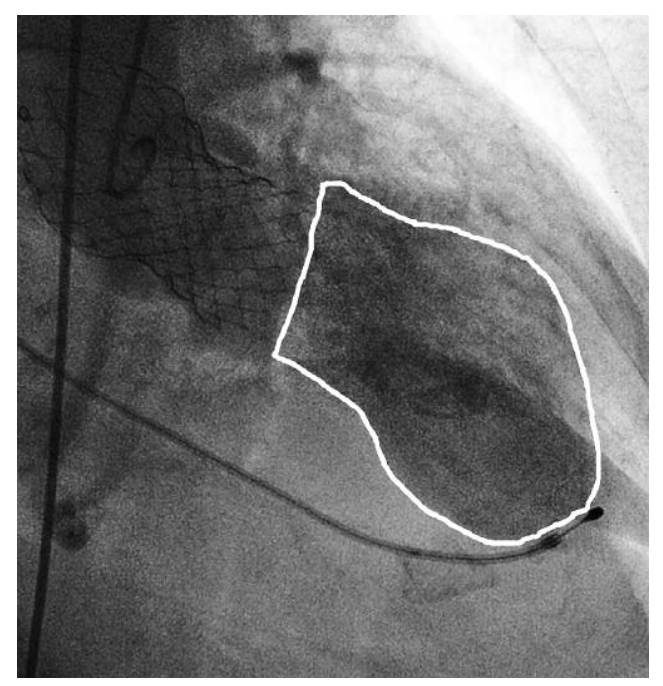

Fig. 2. Cardiac ventriculography - white line outlines regional wall motion abnormalities with apical akinesis of left ventricle

Ryc. 2. Wentrykulografia - biała linią obrysowano obszar regionalnych zaburzeń kurczliwości lewej komory z akineza koniuszka 
ed levels of troponin I up to $1.3 \mathrm{ng} / \mathrm{ml}$ (ULN - $0.07 \mathrm{ng} / \mathrm{ml}$ ) together with chest pain, dyspnoea, ECG changes and normal coronary arteries suggested diagnosis of stress cardiomyopathy.

In further observation hypotension persisted, blood tests revealed elevation of inflammatory markers again, blood cultures were taken and Corynebacterium sp. was found. Haemodynamic parameters were measured with a Swan-Ganz catheter and demonstrated decreased values of cardiac index, cardiac output and systolic volume $\left(\mathrm{Cl}-1.3 \mathrm{l} / \mathrm{min} / \mathrm{m}^{2}\right.$, CO $\left.-2.4 \mathrm{l} / \mathrm{min}, \mathrm{SV}-33.5 \mathrm{ml}\right)$ with low systemic vascular resistance $\left(\mathrm{SVR}-700 \mathrm{dyn} \times \mathrm{s} \times \mathrm{cm}^{-5}\right)$ suggesting the possibility of septic shock. Broad-spectrum antibiotics, fluids, norepinephrine and dobutamine were administered. A few hours later the patient presented cardiac arrest with ventricular fibrillation and was successfully resuscitated with one defibrillation. Within the next days the patient's condition gradually improved. Echocardiography revealed gradual regression of regional wall motion abnormalities and improvement of LVEF.

All the results, age, sex and a history of recent stressrelated procedure confirmed underlying stress cardiomyopathy as one of the causes of the sudden deterioration of the patient's condition. The patient was discharged home 35 days after TAVI and remains under the care of our centre. In long-term follow-up a moderate aortic regurgitation persists with dilation of the left ventricle and elevation of pulmonary pressure but the patient is clinically stable.

\section{Discussion}

Dynamic development of TAVI technique, continuously increasing number of centres performing this procedure as well as the increasing number of valve implantations worldwide provide information on the observed complications of this kind of treatment [3]. This method is still limited to elderly patients with certain risks, in whom complications are expected more often. Generally complications after TAVI may be divided into those related to acute dysfunction of the implanted valve, complications associated with the procedure technique (aortic regurgitation with paravalvular leaks, incorrect location of the valve, acute coronary artery occlusion, cardiac tamponade, aortic annular rupture, aortic dissection, mitral insufficiency, peripheral vessel damage and conduction abnormalities requiring pacemaker implantation) and other general complications, such as peripheral emboli, especially those affecting the central nervous system [2]. The frequency of complications varies in the literature, with the range up to $40 \%$ and with 30 -day mortality up to $12 \%$ [3].

To our knowledge there is not a single case of stress cardiomyopathy described in the available literature as a complication of TAVI procedure. Tako-tsubo cardiomyopathy is usually described as a consequence of severe psychological stress and it could be suspected after every operation which is associated with deep psychological distress [4]. A few cases of stress cardiomyopathy were reported as a complication of varied cardiosurgical procedures [5] and, furthermore, symptoms of stress cardiomyopathy were described in patients of intensive care units, especially in cases of septic shock and multiorgan failure [6]. These combined mechanisms may explain the development of the syndrome in our patient. Typical changes in ECG, moderate elevation in the markers of myocardial damage and gradual recovery of widespread contractility abnormalities contribute to the typical clinical picture.

In conclusion, the presented case indicates the possibility of a less typical complication of TAVI, tako-tsubo syndrome, which should be considered in differential diagnosis of chest pain in patients undergoing this procedure.

\section{Acknowledgments}

This research was financially supported by the National Science Centre (Poland) grant No. 6543/B/T02/2011/40.

\section{References}

1. Webb J, Cribier A. Percutaneous transarterial aortic valve implantation: what do we know? Eur Heart J 2011; 32: 140-147.

2. Leon MB, Piazza N, Nikolsky E, et al. Standardized endpoint definitions for transcatheter aortic valve implantation cllinical trials: a consensus report from the Valve Academic Research Consortium. Eur Heart J 2011; 32: 205-217.

3. Zahn R, Gerckens U, Grube E, et al. Transcatheter aortic valve implantation: first results from a multi-centre real-world registry. Eur Heart J 2011; 32: 198-204.

4. Akashi Y, Nakazawa K, Sakakibara M, et al. The clinical features of takotsubo cardiomyopathy. Int J Med 2002; 96: 563-573.

5. Vernick W, Hargrove W, Augoustides J, Horak J. Takotsubo cardiomyopathy associated with cardiac arrest following cardiac surgery: new variants of an unusual syndrome. J Card Surg 2010; 25 : 679-683.

6. Palacio C, Nugent K, Alalawi R, Cevik C. Severe reversible myocardial depression in a patient with Pseudomonas aeruginosa sepsis suggesting tako-tsubo cardiomyopathy. Int J Cardiol 2009; 135: e16-e19. 